\title{
Current Update of Local Allergic Rhinitis
}

\author{
Su-Jong Kim, Jee Won Moon, and Heung-Man Lee (D) \\ Department of Otorhinolaryngology-Head and Neck Surgery, Guro Hospital, Korea University College of Medicine, Seoul, Korea
}

국소 알레르기비염의 최신지견

김수종 · 문지원 · 이흥만

고려대학교 의과대학 구로병원 이비인후-두경부외과학교실

\author{
Received May 20,2021 \\ Revised July 30, 2021 \\ Accepted August 9, 2021 \\ Address for correspondence \\ Heung-Man Lee, MD, PhD \\ Department of Otorhinolaryngology- \\ Head and Neck Surgery, \\ Guro Hospital, \\ Korea University \\ College of Medicine, \\ 148 Gurodong-ro, Guro-gu, \\ Seoul 08308, Korea \\ Tel $+82-2-2626-3185$ \\ Fax $+82-2-868-0475$
}

E-mail1hman@korea.ac.kr
Local allergic rhinitis (LAR) is a localized nasal allergic response in the absence of systemic atopy. The symptoms, duration, severity, and comorbidities of LAR are similar to those of allergic rhinitis. Although pathophysiology of LAR is not fully understood, in some patients specific IgE can be demonstrated in the nasal secretions. The diagnosis currently relies on the positive results of nasal provocation test. Nasal provocation test has shown high sensitivity and specificity with safety, and is considered as the gold standard. LAR patients benefit from the same therapeutic strategies as allergic rhinitis patients, including the avoidance of allergen exposure and the pharmacotherapy. Effectiveness and safety of allergen immunotherapy open a window of treatment opportunity in LAR. This review provides a current update on LAR. Korean J Otorhinolaryngol-Head Neck Surg 2021;64(8):533-9

Key Words Allergen-specific IgE - Local allergic rhinitis · Nasal provocation test · Non-allergic rhinitis.

\section{서 론}

비염은 고전적으로 알레르기비염과 비-알레르기비염으로 분류되며, 알레르기비염의 진단에서 가장 중요한 두 가지 검 사는 피부단자검사와 혈청 특이 $\mathrm{IgE}$ 검사이다. ${ }^{1)}$ 일반적으로 둘 중 하나 이상이 양성으로 확인되어야 알레르기비염으로 진단할 수 있고, 둘 다 음성인 경우 비-알레르기비염으로 진 단한다. ${ }^{2}$ 하지만, 피부단자검사와 혈청 특이 $\mathrm{IgE}$ 가 모두 음성 인 비-알레르기비염 환자 중에서도 알레르기비염 증상을 보 이는 경우가 관찰되며, 일부에서 비강유발검사상 양성인 것 이 확인된다. 이처럼 전신적인 아토피가 없으나 국소적 알레 르기비염 증상이 있는 상태를 국소 알레르기비염으로 정의 하며, 고전적인 알레르기비염 및 비-알레르기비염의 분류 중 어느 쪽에도 속하지 않는다. ${ }^{3,4)}$ Huggins 등이 처음으로 국소

This is an Open Access article distributed under the terms of the Creative Commons Attribution Non-Commercial License (https://creativecommons.org/licenses/by-nc/4.0) which permits unrestricted non-commercial use, distribution, and reproduction in any medium, provided the original work is properly cited.
알레르기비염의 개념을 제시하였고, 이후 Rondón 등에 의해 서 국소 알레르기비염으로 정의되었다. ${ }^{5-7)}$

최근 수년간 국소 알레르기비염에 대한 연구가 활발히 진 행되고 있으며, 국소 알레르기비염의 역학, 병태생리, 진단 및 치료, 더 나아가 면역치료 효과 등에 대한 최근 연구 동향을 소개하고자 한다.

\section{역 학}

국소 알레르기비염에 대한 연구가 진행되면서 비염 환자 중에서 국소 알레르기비염이 차지하는 비율이 보고되고 있 다. 국내에서 시행된 연구에서 Jung 등은 전체 150 명의 비 염 환자 중에서 $4 \%$ 가 집먼지진드기에 대한 국소 알레르기비 염으로 진단되었다고 보고하였고, $\mathrm{Kim}$ 과 $\mathrm{Jang}^{9}$ 은 국소 알 레르기비염이 전체 비염 환자의 $3.5 \%$ 를 차지한다고 보고하 였다. 중국에서는 Tao 등ํ)이 194명의 비염 환자를 대상으로 시행한 연구에서 $7.7 \%$ 가 국소 알레르기비염으로 진단되었고, 
Cheng 등 ${ }^{11)}$ 의 연구에서는 국소 알레르기비염이 전체 비염의 $8.2 \%$ 를 차지하였다.

서양에서는 국소 알레르기비염이 차지하는 비율이 동양보 다 상대적으로 더 높게 보고되었다. Rondón 등 ${ }^{12)}$ 은 428 명의 비염 환자 중 $25.7 \%$ 에서 국소 알레르기비염으로 진단하였고, Bozek 등 ${ }^{13}$ 의 연구에서는 621 명의 비염 환자 중 $17.6 \%$ 가 국 소 알레르기비염으로 확인되었다. 그 외에도 Hamizan 등 ${ }^{14,15)}$ 이 보고한 체계적 문헌 고찰에서, 3400명 및 648명을 대상으 로 분석하여 국소 알레르기비염이 전체 비염의 각각 $24.7 \%$ 와 $10.2 \%$ 의 비율을 차지하였다.

연구 설계 방법이나 진단 방법 등에서 존재하는 차이로 인 하여 연구 간 유병률 차이가 나타나며, 동양이 서양에 비하 여 비교적 낮은 유병률을 보이는 것은 민족적인 혹은 환경적 인 요인에 기인한다. 추후 대규모 연구가 필요하며, 그럼에도 불구하고 다양한 연구들은 우리나라를 포함한 많은 국가에 서 국소 알레르기비염이 전신적 아토피가 없는 비-알레르기 비염 환자의 상당 부분을 차지한다는 것을 명확히 보여준다.

\section{임상 양상 및 동반 질환}

국소 알레르기비염 환자의 증상은 콧물, 가려움증, 재채기 및 코막힘 등으로 알레르기비염 환자의 증상과 비슷하고, 지 속적이며 통년성 양상을 보이는 경우가 많다. ${ }^{16,17)}$ 아동기 때부 터 증상을 보이는 경우가 $36 \%$ 로 비교적 높고, 비흡연자 여성 에게 가장 흔하다. ${ }^{12)}$ 대표적인 동반 질환으로는 결막염과 천 식이 있으며, 가장 흔한 항원은 집먼지진드기(D. pteronyssinus)이다. ${ }^{18)}$

Rondón 등 ${ }^{18,19)}$ 은 국소 알레르기비염 환자를 10 년간 관찰 하여, 전신적인 아토피로 전환되는 경우는 $9.7 \%$ 였으며 대조 군의 $7.8 \%$ 와 비교하여 유의한 차이가 없었다. 따라서 국소 알레르기비염은 알레르기비염의 시작 단계가 아닌 독자적인 표현형이다. 또한 10 년 기간 동안에 지속적인 비염의 증상은 $64.8 \%$ 에서 $88.6 \%$ 로 증가하였고, 중증 환자도 $1.9 \%$ 에서 $4.2 \%$ 로 유의하게 증가하였다. 천식 의심 증상을 보이는 환자는 $18.8 \%$ 에서 $30.7 \%$ 로 유의하게 증가하였고, forced expiratory volume in one second(FEV1)도 94.1\%에서 89.1\%로 유의하 게 감소하였다. 그 외에도 국소 알레르기비염 환자에서 결막 염 유병률도 $52.3 \%$ 에서 $61.9 \%$ 로 증가하였다. 특히 국소 알레 르기비염 환자에서 삶의 질 장애가 발생한 비율이 $55.1 \%$ 에서 $85.2 \%$ 로 유의하게 증가하였다. ${ }^{19)}$

Campo 등이는 기관지 증상을 호소하는 국소 알레르기비 염 환자 중 $50 \%$ 가 메타콜린 유발 검사에서 양성 반응을 보여 천식으로 진단되었다. 기관지 항원 유발검사상 비-알레르기
비염 환자 혹은 건강한 대조군에서는 한 명도 관찰되지 않은 반면, 국소 알레르기비염 환자에서는 $28 \%$ 에서 양성을 보여 국소 알레르기비염 환자에서도 상기도와 하기도 사이에 병태 생리적 연결고리가 있음을 뒷받침한다. ${ }^{21)}$

요약하면 국소 알레르기비염 환자는 알레르기비염 환자에 서 보이는 콧물, 가려움증, 재채기 및 코막힘 등의 증상을 보 이고, 장기적으로 비염 증상 자체의 악화 및 기관지 증상 유 발 등이 동반되며, 궁극적으로 삶의 질이 저하되고 결막염 및 천식 등의 질환이 동반된다.

\section{병태생리}

Huggins와 Brostoff ${ }^{5)}$ 는 처음으로 전신적인 아토피가 없는 비염 환자의 콧물에서 특이 IgE를 확인하였고, 전신적인 아토 피를 보이지 않는 비염 환자의 코점막에서 특이 $\mathrm{IgE}$ 의 침윤 이 증가한 증례가 보고되었다. 22,23) 이후 국소 알레르기비염이 정의되면서 비강 특이 $\mathrm{IgE}$ 항체와의 연관성을 찾기 위한 많 은 노력이 있었다. Rondón 등,16)은 국소 알레르기비염 환자 중에서 통년성 환자의 $22 \%$, 그리고 계절성 환자의 $35 \%$ 에서 콧물 특이 $\mathrm{IgE}$ 항체를 검출하였다. 그 외에도 국소 알레르기 비염 환자에서의 특이 $\mathrm{IgE}$ 를 찾으려는 연구들에서 비교적 낮은 발견율을 보였으며, 국소 알레르기비염 환자의 병태생 리 내에서 특이 $\operatorname{IgE}$ 의 관여도에 의문이 제기되었다. ${ }^{24)}$

국소 알레르기 반응에서의 면역학적 역할이 명확히 밝혀지 지는 않았지만, 국소 알레르기비염의 발생기전에 특이 $\mathrm{IgE}$ 가 관여한다. 국소 알레르기비염 환자의 일부에서 특이 $\mathrm{IgE}$-매 개 호염기구 반응검사에 양성을 보이고 Wortmannin(PI3K blocker preventing IgE-dependent activation)을 첨가하면 호염기구 반응이 억제되며, 이는 점막의 특이 $\mathrm{IgE}$ 가 혈행으 로 도달함을 의미한다. ${ }^{25-27)}$

알레르기비염 환자의 코점막에서 국소적인 면역 글로불린 종류 변환(class switch recombination)이 발생하며, ${ }^{28,29)}$ 점 막에서 만들어진 특이 $\mathrm{IgE}$ 는 림프체계를 통해 혈행으로 퍼 지고, 궁극적으로 말초 조직으로 퍼져 피부 등에 존재하는 비만세포를 감작시키거나 호염기구를 통해 순환한다. ${ }^{30,31)}$ 천 식 환자에서 전신적인 아토피 상태와 상관없이 기관지 점막 내에서 면역 글로불린 종류변환이 일어난다는 근거가 확인되 었고, ${ }^{32)}$ 국소 알레르기비염 환자 코점막에서도 효과기 세포 를 감작시키는 수준의 특이 $\operatorname{IgE}$ 생성이 가능하지만, 피부 등 말초 비만세포에 도달하거나 혈행에서 관찰되지 않는 수준 일 것으로 추정된다(Fig. 1). 


\section{진 단}

피부단자검사와 혈청 특이 $\mathrm{IgE}$ 가 음성으로 전신적인 아토 피가 없는 환자 중에서 알레르기비염의 증상이 있을 때에 국 소 알레르기비염을 의심할 수 있으며, 진단에서 가장 중요한 검사는 비강유발검사이다. 비강에 항원을 투여하여 코점막을 항원에 노출시켜 발생하는 임상증상의 변화와 비강 저항, 부 피 및 단면적 등의 변화를 측정하여 알레르기 반응을 평가한 다. ${ }^{33)}$ 비강유발검사는 국소 알레르기비염을 진단하는 데에 민 감도와 특이도가 가장 높은 검사이며, ${ }^{34-36)}$ European Academy of Allergy and Clinical Immunology(EAACI)는 국소 알레르기비염 진단의 가장 중요한 기준으로 제시하였다. ${ }^{37}$

전신적인 아토피를 보이지 않는 비염 환자에서 비강유발검 사상 양성이 나오는 비율, 즉 비-알레르기비염 환자 중에서 비강유발검사를 통하여 국소 알레르기비염으로 진단되는 유 병률이 3.5\% 50.0\% 정도까지 매우 다양하다. ${ }^{3,7-9,17)}$ 이는 각 연구자마다 사용하는 항원의 종류 및 농도가 다르고 유발 전후 평가하는 척도 등이 차이가 있기 때문이다. ${ }^{38)} \mathrm{EAACI}$ 에 서는 이를 보완하고자 비강유발검사의 절차를 정립하였다. ${ }^{37}$ 항원은 다양한 제조업체에서 표준화된 용액으로 판매되고,
비강유발검사와 같이 임상적인 목적으로 사용하는 경우에는 제조업체의 지침을 참고하여 사용한다. 항원의 적용방법은 펌프-에어로졸 스프레이(pump-aerosol spray) 형태가 가장 편하고 신뢰할 수 있으며, 한번의 펌프로 $50 \mu \mathrm{L}$ 를 분사한다. 검사 시에는 콧구멍 당 두번씩 분사하며(하비도 1회 및 중비 도 1회), 기계적 자극을 방지하기 위해 비중격 방향으로 분사 하는 것을 피한다. 검사 과정은 기준 측정, 대조 검사와 항원 검사의 3 가지 단계로 구성되고 각 단계에서 주관적인 척도와 객관적인 척도를 이용하여 반응 여부를 평가하며, Fig. 2와 같은 프로토콜에 따라 검사 결과를 판정한다. 반응을 평가 하는 주관적인 척도로는 시각아날로그척도 혹은 총 코증상 점수 등을 이용하고, 객관적인 척도로는 비강최대흡기유속검 사, 비강통기도검사, 음향비강통기도검사 및 4단계-비강통기 도검사를 이용하여 코개방성을 측정한다(Table 1). 이후 주 관적인 증상과 객관적인 척도 변화에 따라 반응을 판정하며, 주관적인 증상 혹은 객관적인 척도 둘 중 하나라도 강한 반 응을 보이거나, 혹은 둘 다 중등도 이상의 반응을 보이는 경 우에 양성 반응으로 판정한다. ${ }^{37}$

Eguiluz-Gracia 등 ${ }^{39)}$ 의 연구에서 성인 5830명과 소아 518 명을 대상으로 11499 번의 비강유발검사를 시행하여 1547명

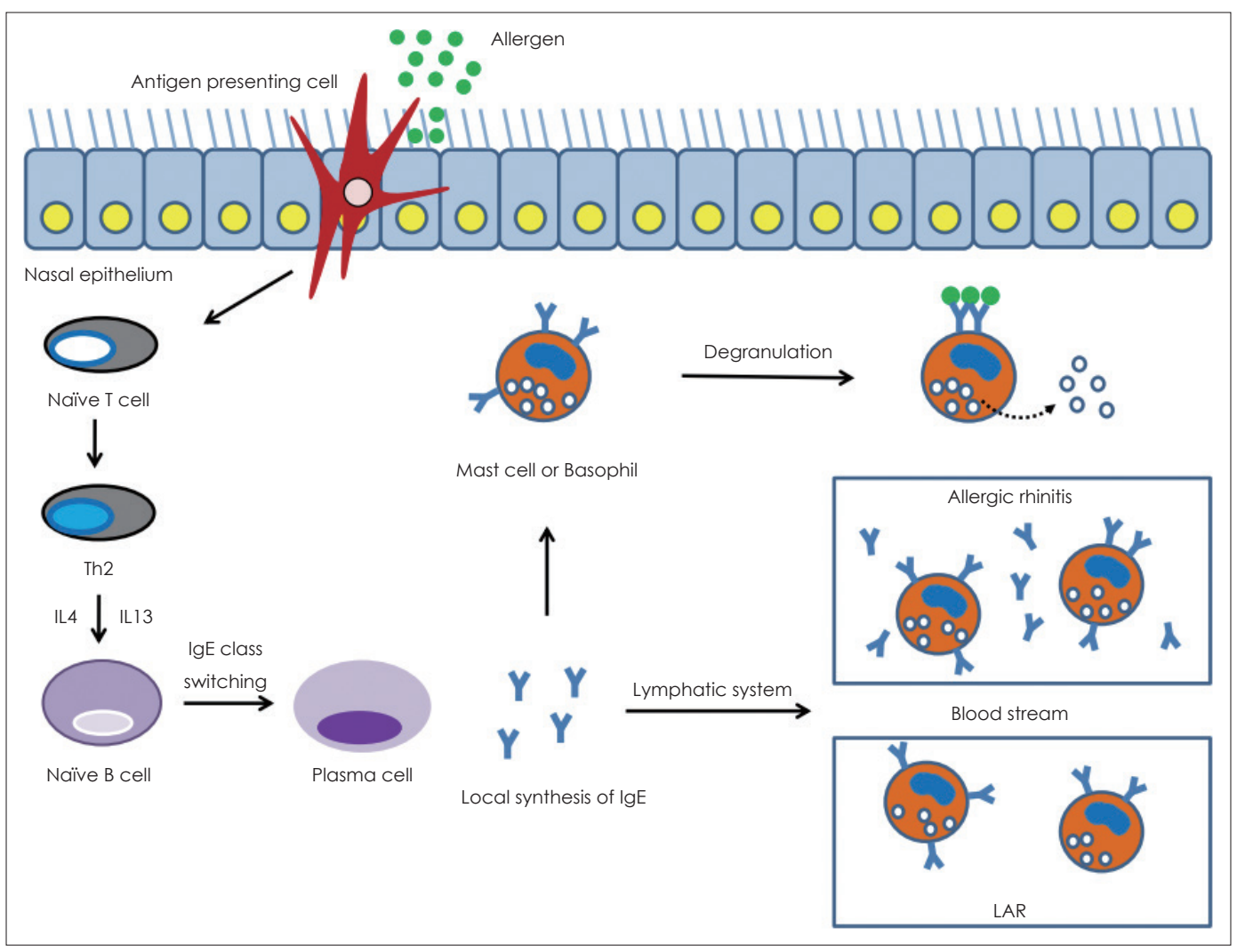

Fig. 1. The IgE-mediated hypersensitivity response has been found to occur in nasal mucosa of LAR patients. After saturating the receptor system of basophils in serum and mast cells in peripheral tissues, IgE can be found at a free state in blood stream of allergic rhinitis patients. On the contrary, in LAR patients, IgE is not enough to be shown at a free state in serum. LAR: local allergic rhinitis. 
에서 증상이 유발되었으나 $99.9 \%$ 에서 증상이 안정적으로 조 절되어 매우 안전한 검사임을 확인하였다. 비강유발검사는 국소 알레르기비염의 진단에 가장 중요한 검사로, 안전하고 우수하며 임상에서 시행하기에도 어렵지 않은 검사이다. 정 형화된 비강유발검사를 이용하여 더 큰 대규모 연구가 시행

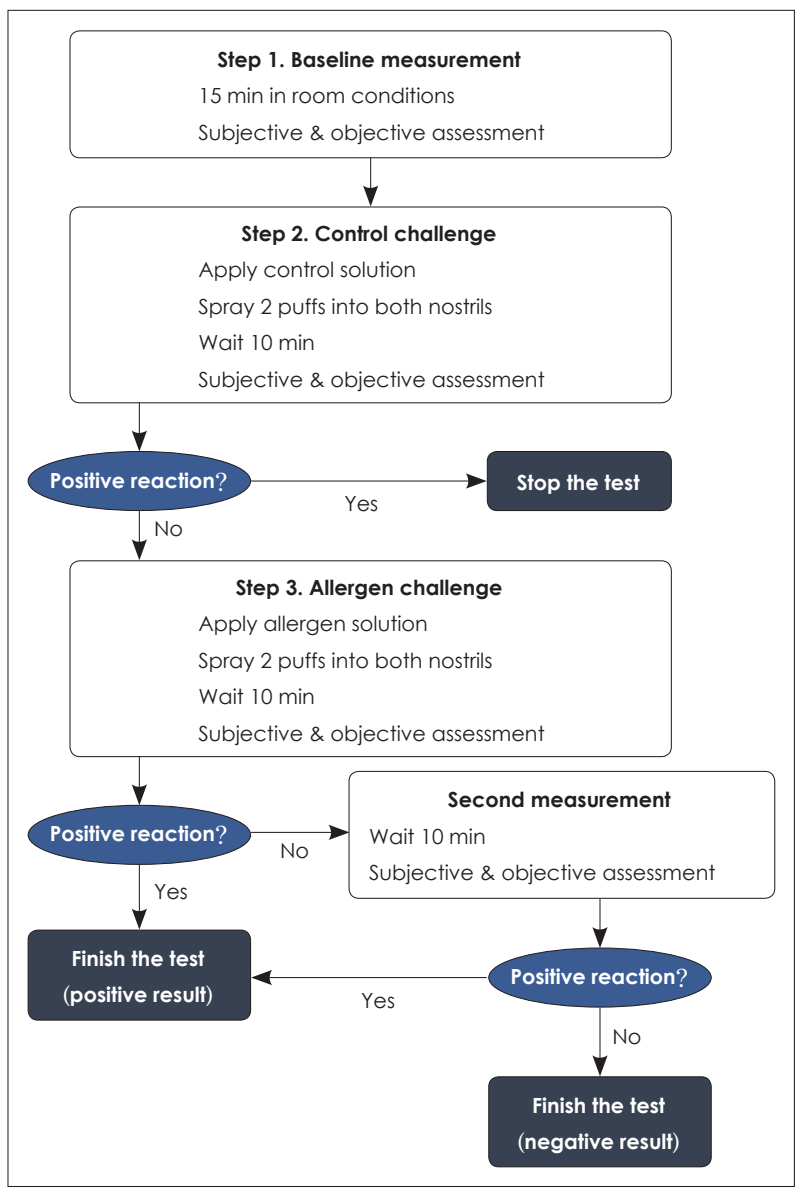

Fig. 2. Procedure of nasal provocation test (modified from the position paper of European Academy of Allergy and Clinical Immunology).
된다면 보다 정교하고 우수한 진단 기준을 정립할 수 있을 것이다.

비강유발검사 외에도 비강에서 특이 $\mathrm{IgE}$ 를 검출하는 것도 진단에 도움이 되며 콧물이나 코 점막조직 등을 이용한 다양 한 방법이 연구되고 있으나, 국소 알레르기비염의 진단에 사 용하기에는 민감도가 다소 낮고 임상에서 사용하기에도 어려 운 문제점이 있다. 실제로 콧물 특이 $\mathrm{IgE}$ 를 이용한 경우 민감 도가 22\% 40\%이며, ${ }^{3,16)}$ 비강유발을 시행한 이후에 특이 IgE 를 측정한 경우에도 비슷한 정도로 낮게 측정되었는데, 이는 희석효과 등이 원인으로 추정된다. ${ }^{40,41)}$

다른 보조적인 방법으로는 유세포 분석을 기반으로 하는 호염기구 활성화 검사가 있다. 항원으로 자극한 후 호염기구 표면에 나타나는 CD63 혹은 CD203c의 활성 표지자를 측정 하는 검사로, $\mathrm{CD} 63$ 은 $\mathrm{IgE}$-매개 알레르기 반응과 매우 연관 이 높다. ${ }^{42)}$ 국소 알레르기비염의 진단에서 호염기구 활성화 검사의 민감도는 $50.0 \%$ 66.6\%이고, 특이도는 90.0\% 91.7\% 이다. ${ }^{26)}$ 그러나 호염기구 활성화 검사는 실험실적으로만 사 용하고 임상적인 목적으로는 사용이 어렵다.

\section{치 료}

국소 알레르기비염과 알레르기비염은 많은 공통된 임상적 및 병태생리학적 특성을 보이며, 치료도 비슷하다.4) 알레르기 비염 치료와 같이 비강 국소 스테로이드분무제 및 경구 항히 스타민제는 증상 조절에 도움이 되며, 항원 회피요법도 병행 하는 것이 권장된다. ${ }^{3,16)}$ 하지만, 단순한 증상 조절은 국소 알 레르기비염의 병적 진행을 막을 수 없고 항원 회피요법도 불 가피한 상황이 있을 수밖에 없으며, 장기적으로 동반 질환이 발생하고 비염 증상을 악화시킨다.

면역치료는 알레르기비염과 천식의 자연진행 과정을 변화

Table 1. Recommendations for interpretation of subjective and objective assessment after nasal allergen challenge (cited from the position paper of European Academy of Allergy and Clinical Immunology)

\begin{tabular}{|c|c|c|}
\hline Methods & Strongly positive & Moderately positive \\
\hline \multicolumn{3}{|l|}{ Subjective assessment } \\
\hline Visual analog scale & Symptoms $\geq 55 \mathrm{~mm}$ & Symptoms $\geq 23 \mathrm{~mm}$ \\
\hline Lebel score & Increase of $\geq 5$ points & Increase of $\geq 3$ points \\
\hline Linder score & Increase of $\geq 5$ points & Increase of $\geq 3$ points \\
\hline Total nasal symptom score & Increase of $\geq 5$ points & Increase of $\geq 3$ points \\
\hline \multicolumn{3}{|l|}{ Objective assessment } \\
\hline Peak nasal inspiratory flow & Flow decrease of $\geq 40 \%$ & Flow decrease of $\geq 20 \%$ \\
\hline Acoustic rhinometry & Nasal cross section area- 2 decrease of $\geq 40 \%$ & Decrease in sum of $2-6 \mathrm{~cm}^{3} \geq 27 \%$ bilaterally \\
\hline Active anterior rhinomanometry & Flow decrease of $\geq 40 \%$ at $150 \mathrm{~Pa}$ & Flow decrease in $>20 \%$ at $150 \mathrm{~Pa}$ \\
\hline 4-phase rhinomanometry & $\begin{array}{l}\geq 40 \% \text { increase in logarithmic effective } \\
\text { resistance }\end{array}$ & $\begin{array}{l}\geq 20 \% \text { increase in logarithmic effective } \\
\text { resistance }\end{array}$ \\
\hline
\end{tabular}


시킬 수 있는 근본적인 치료법으로 국소 알레르기비염에서도 치료 방법으로 제시되어, 국소 알레르기비염 환자에서 피하 면 역치료의 효과를 분석하는 연구들이 진행되었다(Table 2). ${ }^{43-47)}$ Rondón 등 ${ }^{43)}$ 은 목초 꽃가루에 대한 반응성이 있는 국소 알 레르기비염 환자를 대상으로 6개월간의 피하 면역치료 후 약 물치료를 추가한 군에서 약물치료만 시행한 군보다 증상 및 객관적인 지표에서 더 양호한 결과를 보였다. 이후 피하 면역 치료가 국소 알레르기비염의 치료에 이득이 있을 것으로 생 각하고 추가적인 연구를 시행하였다. Rondón 등 ${ }^{44)}$ 은 2016년 에 집먼지 진드기(D. pteronyssinus)를 항원으로 피하 면역치 료 후 6개월째부터 치료군에서 코 증상 및 약물복용점수가 현저히 감소하였고, 비강유발검사에 대한 관용성은 증가하였 다. 12 개월째부터는 혈청 특이 $\mathrm{IgG} 4$ 수치도 대조군에 비하여 증가하였다. 2018년에는 56명의 환자를 A그룹과 B그룹으로 나누어 분석하였고, A그룹은 플레옴(Phleum pratense)을 항 원으로 2 년간 피하 면역치료를 받았고, B그룹은 1 년은 위약 치료를 받은 후 1 년은 피하 면역치료를 받았다. 첫 해는 $A$ 그 룹에서 $\mathrm{B}$ 그룹과 비교하여 코 증상 및 약물복용점수가 유의 하게 감소하였고, 천식 조절도 유의미한 차이가 있었다. 두 번 째 해에는 두 그룹 모두 면역치료를 받았으며, 첫 번째 해에 비교하여 두 그룹 모두 코 증상 및 약물복용점수가 유의하게 감소하였다. 이를 통해 피하 면역치료가 단기간 및 장기간 모 두에 효과가 있음을 입증하였다. ${ }^{45}$
Bozek 등 ${ }^{46,47)}$ 이 자작나무(Betula verrucosa)를 항원으로 시행한 두 임상시험에서도 유의한 치료효과를 보였다. 2018 년에 보고한 임상시험에서는 24개월 동안 면역치료를 시행한 치료군에서 코증상 및 약물복용점수가 유의하게 감소하였 고, 혈청 특이 $\mathrm{IgG} 4$ 가 증가하지만 비강 특이 $\mathrm{IgE}$ 는 감소하였 다. ${ }^{46)}$ 2020년 연구에서는 3년간의 면역치료를 시행한 그룹과 위약군을 비교하여 앞선 연구와 비슷한 임상적 및 면역학적 결과를 얻었고, 치료군에서 피하 면역치료 이후에 기관지 반 응성이 유의하게 감소하였다. ${ }^{47)}$

이처럼 피하 면역치료는 증상점수, 약을 복용하지 않는 날 짜, 삶의 질, 비강유발검사에 대한 관용성 등 다양한 임상적 치료효과를 보이며, 혈청 및 비강 특이 $\mathrm{IgE}$ 가 감소하고 혈청 특이 $\mathrm{IgG} 4$ 가 증가하는 등의 면역학적 치료효과를 보였다. 기 관지 반응성을 감소시키고 천식을 조절하는 효과도 보이고, 면역치료 시에 단 몇 건의 국소 반응 외에 중대한 부작용이 발생하지 않아 안전한 치료이다. 따라서 피하 면역치료는 치 료효과와 안전성이 입증된 국소 알레르기비염의 중요한 치료 옵션이다. 피하 면역치료 종결 후 치료 효과가 장기간 유지되 는지, 설하 면역치료도 비슷한 치료효과가 있는지, 또는 수술 적 치료는 어떠한 역할을 할 수 있는지 등에 대하여는 추후 연구가 필요하다.

Table 2. Treatment outcomes of allergen immunotherapy in LAR

\begin{tabular}{|c|c|c|c|c|c|c|}
\hline $\begin{array}{l}\text { Author } \\
\text { (years) }\end{array}$ & Design & $\begin{array}{c}\text { No. of } \\
\text { patients }\end{array}$ & $\begin{array}{l}\text { Duration } \\
\text { (months) }\end{array}$ & Allergen extract & Primary outcome & Secondary Outcome \\
\hline $\begin{array}{l}\text { Rondón, } \\
\text { et al. }^{43)}(2011)\end{array}$ & $\begin{array}{l}\text { Open } \\
\text { observational }\end{array}$ & 20 & 6 & Grass pollen & $\uparrow$ Nasal tolerance to NAPT & $\begin{array}{l}\downarrow C S M S \\
\uparrow M F D \\
\downarrow \text { Severity of LAR symptoms }\end{array}$ \\
\hline $\begin{array}{l}\text { Rondón, } \\
\text { et al. }^{44)}(2016)\end{array}$ & RDBPC & 36 & 24 & D. pteronyssinus & $\begin{array}{l}\downarrow \text { Total daily symptoms } \\
\downarrow \text { Total daily medication } \\
\text { scores } \\
\downarrow \text { CSMS } \\
\uparrow \text { MFD }\end{array}$ & $\begin{array}{l}\uparrow \text { Nasal tolerance to NAPT } \\
\uparrow \text { Serum slgG4 } \\
\downarrow \text { Adverse event }\end{array}$ \\
\hline $\begin{array}{l}\text { Rondón, } \\
\text { et al. }^{45)}(2018)\end{array}$ & RDBPC & 56 & 24 & Phleum pratense & $\downarrow C S M S$ & $\begin{array}{l}\downarrow \text { Organ-specific symptoms } \\
\uparrow M F D \\
\downarrow \text { Rhinitis severity } \\
\uparrow \text { Asthma control } \\
\uparrow \text { Nasal tolerance to NAPT } \\
\uparrow \text { Serum slgG4 }\end{array}$ \\
\hline $\begin{array}{l}\text { Bozek, et al. }{ }^{46)} \\
(2018)\end{array}$ & RDBPC & 28 & 24 & Betula verrucosa & $\downarrow C S M S$ & 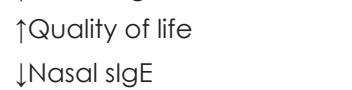 \\
\hline $\begin{array}{l}\text { Bozek, et al. }{ }^{47)} \\
(2020)\end{array}$ & RDBPC & 34 & 36 & Betula verrucosa & $\begin{array}{l}\downarrow C S M S \\
\uparrow \text { Nasal tolerance to NAPT } \\
\downarrow \text { Bronchial responsiveness }\end{array}$ & $\begin{array}{l}\uparrow Q \text { uality of life } \\
\uparrow \text { Serum slgE } \\
\uparrow \text { Serum slgG4 }\end{array}$ \\
\hline
\end{tabular}

NAPT: nasal allergen provocation test, CSMS: combined symptom and medication score, MFD: medication free days, LAR: local allergic rhinitis, RDBPC: randomized, double-blind, placebo-controlled 


\author{
결 론 \\ 국소 알레르기비염은 전체 비염 환자의 상당한 부분을 차 \\ 지하고 있음에도 불구하고 진단이나 치료와 같은 임상적인 \\ 연구가 부족하다. 국소 알레르기비염은 주로 아동기에 시작 \\ 되어서 점차 악화되며 기관지 증상 유발이나 결막염과 같은 \\ 질환을 동반한다. 가장 중요한 진단방법은 비강유발검사로 \\ 적절한 약물치료와 면역치료를 통해 질병의 진행을 막는 것 \\ 이 중요하다.
}

\section{Acknowledgments}

None.

\section{Author Contribution}

Conceptualization: all authors. Data curation: Jee Won Moon. Formal analysis: all authors. Funding acquisition: Heung-Man Lee. Investigation: Su-Jong Kim, Jee Won Moon. Methodology: HeungMan Lee. Project administration: Su-Jong Kim, Heung-Man Lee. Resources: Su-Jong Kim. Software: Jee Won Moon. Supervision: Heung-Man Lee. Validation: Heung-Man Lee. Visualization: SuJong Kim, Jee Won Moon. Writing — original draft: Su-Jong Kim. Writing — review \& editing: Su-Jong Kim.

\section{ORCID}

Heung-Man Lee https://orcid.org/0000-0003-4774-4739

\section{REFERENCES}

1) Bousquet J, Khaltaev N, Cruz AA, Denburg J, Fokkens WJ, Togias A, et al. Allergic rhinitis and its impact on asthma (ARIA) 2008. Allergy 2008;63 Suppl 86:8-160.

2) Greiner AN, Hellings PW, Rotiroti G, Scadding GK. Allergic rhinitis. Lancet 2011;378(9809):2112-22.

3) Rondón C, Romero JJ, López S, Antúnez C, Martín-Casañez E, Torres MJ, et al. Local IgE production and positive nasal provocation test in patients with persistent nonallergic rhinitis. J Allergy Clin Immunol 2007;119(4):899-905.

4) Rondón C, Campo P, Togias A, Fokkens WJ, Durham SR, Powe DG, et al. Local allergic rhinitis: Concept, pathophysiology, and management. J Allergy Clin Immunol 2012;129(6):1460-7.

5) Huggins KG, Brostoff J. Local production of specific IgE antibodies in allergic-rhinitis patients with negative skin tests. Lancet 1975; 306(7926):148-50.

6) Rondón C, Canto G, Blanca M. Local allergic rhinitis: A new entity, characterization and further studies. Curr Opin Allergy Clin Immunol 2010;10(1):1-7.

7) Powe DG, Jagger C, Kleinjan A, Carney AS, Jenkins D, Jones NS. 'Entopy': Localized mucosal allergic disease in the absence of systemic responses for atopy. Clin Exp Allergy 2003;33(10):1374-9.

8) Jung CG, Lee JH, Ban GY, Park HS, Shin YS. Prevalence and clinical characteristics of local allergic rhinitis to house dust mites. Yonsei Med J 2017;58(5):1047-50.

9) Kim YH, Jang TY. Clinical characteristics and therapeutic outcomes of patients with localized mucosal allergy. Am J Rhinol Allergy 2010;24(4):e89-92.

10) Tao XY, Ng CL, Chen D, Lin ZB, Wu SL, Liang MJ, et al. Clinical characteristics and allergen sensitization patterns of patients with local allergic rhinitis in southern China. Int Arch Allergy Immunol 2018;175(1-2):107-13.
11) Cheng KJ, Xu YY, Liu HY, Wang SQ. Serum eosinophil cationic protein level in Chinese subjects with nonallergic and local allergic rhinitis and its relation to the severity of disease. Am J Rhinol Allergy 2013;27(1):8-12.

12) Rondón C, Campo P, Galindo L, Blanca-López N, Cassinello MS, Rodriguez-Bada JL, et al. Prevalence and clinical relevance of local allergic rhinitis. Allergy 2012;67(10):1282-8.

13) Bozek A, Scierski W, Ignasiak B, Jarzab J, Misiolek M. The prevalence and characteristics of local allergic rhinitis in Poland. Rhinology 2019;57(3):213-8.

14) Hamizan AW, Rimmer J, Alvarado R, Sewell WA, Kalish L, Sacks $\mathrm{R}$, et al. Positive allergen reaction in allergic and nonallergic rhinitis: A systematic review. Int Forum Allergy Rhinol 2017;7(9): 868-77.

15) Hamizan AW, Rimmer J, Husain S, Alvarado R, Tatersall J, Sewell $\mathrm{W}$, et al. Local specific Immunoglobulin $\mathrm{E}$ among patients with nonallergic rhinitis: A systematic review. Rhinology 2019;57(1):1020.

16) Rondón C, Doña I, López S, Campo P, Romero JJ, Torres MJ, et al. Seasonal idiopathic rhinitis with local inflammatory response and specific IgE in absence of systemic response. Allergy 2008;63(10): $1352-8$.

17) Rondón C, Fernández J, López S, Campo P, Doña I, Torres MJ, et al. Nasal inflammatory mediators and specific IgE production after nasal challenge with grass pollen in local allergic rhinitis. J Allergy Clin Immunol 2009;124(5):1005-11.e1.

18) Rondón C, Campo P, Zambonino MA, Blanca-Lopez N, Torres MJ, Melendez L, et al. Follow-up study in local allergic rhinitis shows a consistent entity not evolving to systemic allergic rhinitis. J Allergy Clin Immunol 2014;133(4):1026-31.

19) Rondon C, Campo P, Eguiluz-Gracia I, Plaza C, Bogas G, Galindo $\mathrm{P}$, et al. Local allergic rhinitis is an independent rhinitis phenotype: The results of a 10-year follow-up study. Allergy 2018;73(2):470-8.

20) Campo P, Eguiluz-Gracia I, Plaza-Serón MC, Salas M, José Rodríguez M, Pérez-Sánchez N, et al. Bronchial asthma triggered by house dust mites in patients with local allergic rhinitis. Allergy 2019;74(8):1502-10.

21) Brożek JL, Bousquet J, Agache I, Agarwal A, Bachert C, BosnicAnticevich S, et al. Allergic rhinitis and its impact on asthma (ARIA) guidelines-2016 revision. J Allergy Clin Immunol 2017;140(4):950-8.

22) Powe DG, Huskisson RS, Carney AS, Jenkins D, Jones NS. Evidence for an inflammatory pathophysiology in idiopathic rhinitis. Clin Exp Allergy 2001;31(6):864-72.

23) Carney AS, Powe DG, Huskisson RS, Jones NS. Atypical nasal challenges in patients with idiopathic rhinitis: More evidence for the existence of allergy in the absence of atopy? Clin Exp Allergy 2002;32(10):1436-40.

24) Powe DG, Groot Kormelink T, Sisson M, Blokhuis BJ, Kramer MF, Jones NS, et al. Evidence for the involvement of free light chain immunoglobulins in allergic and nonallergic rhinitis. J Allergy Clin Immunol 2010;125(1):139-45.

25) Campo P, Villalba M, Barrionuevo E, Rondón C, Salas M, Galindo $\mathrm{L}$, et al. Immunologic responses to the major allergen of Olea europaea in local and systemic allergic rhinitis subjects. Clin Exp Allergy 2015;45(11):1703-12.

26) Duarte Ferreira R, Ornelas C, Silva S, Morgado R, Pereira D, Escaleira D, et al. Contribution of in vivo and in vitro testing for the diagnosis of local allergic rhinitis. J Investig Allergol Clin Immunol 2019;29(1):46-8.

27) Gómez E, Campo P, Rondón C, Barrionuevo E, Blanca-López N, Torres MJ, et al. Role of the basophil activation test in the diagnosis of local allergic rhinitis. J Allergy Clin Immunol 2013;132(4):975-6.

28) Coker HA, Durham SR, Gould HJ. Local somatic hypermutation and class switch recombination in the nasal mucosa of allergic 
rhinitis patients. J Immunol 2003;171(10):5602-10.

29) Takhar P, Smurthwaite L, Coker HA, Fear DJ, Banfield GK, Carr $\mathrm{VA}$, et al. Allergen drives class switching to IgE in the nasal mucosa in allergic rhinitis. J Immunol 2005;174(8):5024-32.

30) Min B, Paul WE. Basophils: In the spotlight at last. Nat Immunol 2008;9(3):223-5.

31) Falcone FH, Knol EF, Gibbs BF. The role of basophils in the pathogenesis of allergic disease. Clin Exp Allergy 2011;41(7):939-47.

32) Takhar P, Corrigan CJ, Smurthwaite L, O'Connor BJ, Durham SR, Lee TH, et al. Class switch recombination to IgE in the bronchial mucosa of atopic and nonatopic patients with asthma. J Allergy Clin Immunol 2007;119(1):213-8.

33) Gosepath J, Amedee RG, Mann WJ. Nasal provocation testing as an international standard for evaluation of allergic and nonallergic rhinitis. Laryngoscope 2005;115(3):512-6.

34) Jang TY, Kim YH. Nasal provocation test is useful for discriminating allergic, nonallergic, and local allergic rhinitis. Am J Rhinol Allergy 2015;29(4):e100-4.

35) Rondón C, Eguiluz-Gracia I, Campo P. Is the evidence of local allergic rhinitis growing? Curr Opin Allergy Clin Immunol 2018; 18(4):342-9.

36) Campo P, Eguiluz-Gracia I, Bogas G, Salas M, Plaza Serón C, Pérez N, et al. Local allergic rhinitis: Implications for management. Clin Exp Allergy 2019;49(1):6-16.

37) Augé J, Vent J, Agache I, Airaksinen L, Campo Mozo P, Chaker A, et al. EAACI position paper on the standardization of nasal allergen challenges. Allergy 2018;73(8):1597-608.

38) Alvares ML, Khan DA. Allergic rhinitis with negative skin tests. Curr Allergy Asthma Rep 2011;11(2):107-14.

39) Eguiluz-Gracia I, Testera-Montes A, González M, Pérez-Sánchez
N, Ariza A, Salas M, et al. Safety and reproducibility of nasal allergen challenge. Allergy 2019;74(6):1125-34.

40) Campo P, Rondón C, Gould HJ, Barrionuevo E, Gevaert P, Blanca M. Local IgE in non-allergic rhinitis. Clin Exp Allergy 2015;45(5): $872-81$.

41) Rondón C, Eguíluz-Gracia I, Shamji MH, Layhadi JA, Salas M, Torres MJ, et al. IgE test in secretions of patients with respiratory allergy. Curr Allergy Asthma Rep 2018;18(12):67.

42) Hoffmann HJ, Santos AF, Mayorga C, Nopp A, Eberlein B, Ferrer M, et al. The clinical utility of basophil activation testing in diagnosis and monitoring of allergic disease. Allergy 2015;70(11):1393-405.

43) Rondón C, Blanca-López N, Aranda A, Herrera R, RodriguezBada JL, Canto G, et al. Local allergic rhinitis: Allergen tolerance and immunologic changes after preseasonal immunotherapy with grass pollen. J Allergy Clin Immunol 2011;127(4):1069-71.

44) Rondón C, Campo P, Salas M, Aranda A, Molina A, González M, et al. Efficacy and safety of D. pteronyssinus immunotherapy in local allergic rhinitis: A double-blind placebo-controlled clinical trial. Allergy 2016;71(7):1057-61.

45) Rondón C, Blanca-López N, Campo P, Mayorga C, Jurado-Escobar $\mathrm{R}$, Torres MJ, et al. Specific immunotherapy in local allergic rhinitis: A randomized, double-blind placebo-controlled trial with Phleum pratense subcutaneous allergen immunotherapy. Allergy 2018; 73(4):905-15.

46) Bożek A, Kołodziejczyk K, Jarząb J. Efficacy and safety of birch pollen immunotherapy for local allergic rhinitis. Ann Allergy Asthma Immunol 2018;120(1):53-8.

47) Bozek A, Winterstein J, Galuszka B, Jarzab J. Different development forms of local allergic rhinitis towards birch. Biomed Res Int 2020;2020:3408561.

\section{정답 및 해설}

답 (2)

해 설 참고 문헌: 대한이비인후과학회. 이비인후과학:두경부. 개정2판. 파주: 군자출판사;2018. p.414-5. 